\title{
Nota Técnica: \\ Patologías y estudio analítico de materiales procedentes de mosaicos de Carmona e Itálica
}

\author{
Technical Note: \\ Pathologies and analytical study of mosaic materials from Carmona \\ and Italica
}

\author{
T. Palomar $^{(*)}$, M. García-Heras ${ }^{(*)}$, C. Saiz-Jiménez ${ }^{(* *)}$, C. Márquez ${ }^{(* * *)}$, M. A. Villegas ${ }^{(*)}$
}

Recepción/Received: 23-XI-10

Aceptación/Accepted: 3-III-11

Publicado online/Online publishing: 18-VII-11

\section{RESUMEN}

Este trabajo presenta los resultados del estudio realizado en muestras de mosaicos romanos procedentes de Carmona e Itálica (Sevilla). El objetivo principal del estudio consistió en la caracterización químico-física de teselas de vidrio y fragmentos de mortero para determinar su composición, evaluar su estado de conservación y estudiar su tecnología de producción. Las muestras se caracterizaron mediante lupa binocular, MEB-EDS, espectrofotometría visible, DRX y análisis petrográfico. Los resultados indicaron que las teselas se realizaron con vidrio de silicato sódico cálcico, aunque una de ellas mostró elevados contenidos de óxidos de plomo y de cobre. Las muestras procedentes de Carmona presentaron patologías de deterioro asociadas a la humedad retenida por el mosaico durante su enterramiento, mientras que las muestras de Itálica presentaron huellas de biodeterioro. Asimismo, los resultados indicaron que en las teselas se utilizó un vidrio de inferior calidad técnica que el empleado en piezas de vajilla de cronología semejante.

Palabras clave: teselas, vidrio, mortero, romano, deterioro.

\section{SUMMARY}

This work reports on the characterization of Roman mosaic samples from Carmona and Italica (Spain). A physico-chemical study of both glass tesserae and mortar fragments to determine their composition, to evaluate their state of conservation and to study their production technology was carried out. Samples were characterized by means of a binocular microscope, SEM$E D S$, visible spectrophotometry, XRD and petrographic analysis. The tesserae were made from soda lime silicate glass, even though one of them showed high contents of lead and copper oxides. The samples from Carmona showed deterioration pathologies associated to the humidity affecting the mosaic during burial, while those from Italica presented traces of biodeterioration. The data also indicated that the glass used in the tesserae had a lower technical quality than that used in tableware pieces of similar chronology.

Keywords: tesserae, glass, mortar, roman, deterioration.

(*) Instituto de Historia, Centro de Ciencias Humanas y Sociales, CSIC (Madrid, España).

(**) Instituto de Recursos Naturales y Agrobiología, CSIC (Sevilla, España).

(***) Restauradora (Sevilla, España) 


\section{INTRODUCTION}

The mosaic has been used throughout the History as a decorative item, even though it also plays a structural function since it is part of a floor or wall. They are composed of different layers named statumen, rudus, nucleus, mortar and the tesserae final layer (Figure 1a). The preparation of a Roman mosaic was documented by Vitrubio in De Architectura and by Plinio in Naturalis Historia libri. The first step of the process consisted on setting the statumen (formed by coarse stones), followed by the rudus (a lime and sand mortar mixed with stone fragments). Then the nucleus was added, which was composed of a lime mortar and finer elements such as grounded bricks or marble powder. On the nucleus the sinopia (a coloured design) was accomplished by means of ceramic or lead patterns, rules, strings, sectors, and other tools. Finally the tesserae were inserted $(1,2)$. These pieces, in general, were cubic in shape and could be produced on stone, marble, ceramic or glass. The different colouring of the tesserae allowed the elaboration from simple geometric motifs to complex figurative representations.

The most ancient mosaics were used as wall decoration. In the ancient city of Uruk (Fourth millennium $\mathrm{BC})$, very simple geometrical motifs made of fired clay with black, red and white colours were found. During the seventh to the third centuries $B C$, the mosaics made with river or sea pebble stones were expanded throughout the Mediterranean basin. They were mainly used for decorating temples and sanctuary floors. This kind of mosaics was usually produced for private houses up to the first century BC. Nevertheless, the higher

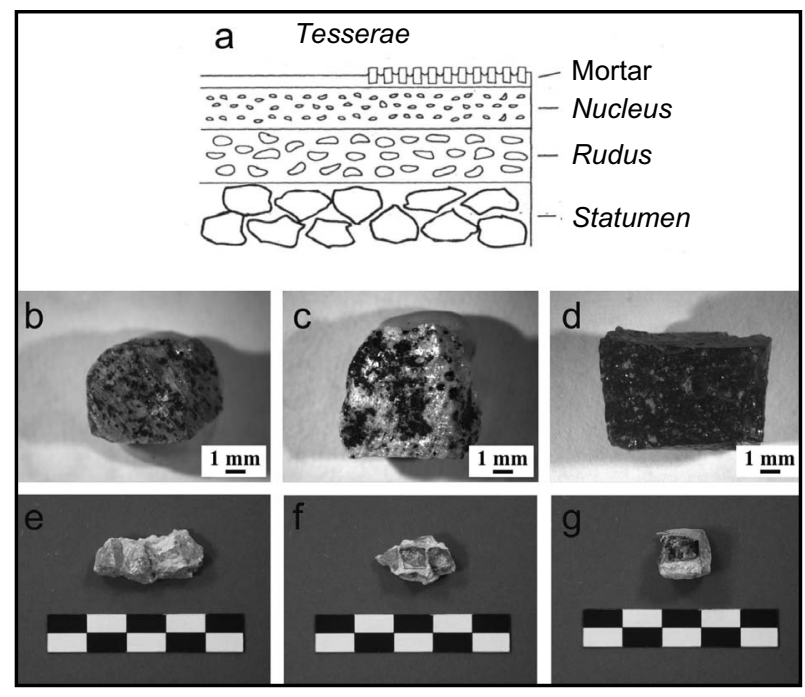

Figure 1. a) Cross-section scheme of a classic mosaic pavement according to reference (2), b) Image from sample C-7, c) Image from sample C-12, d) Image from sample I-3, e) Image from sample C-3. f) Image from sample C-5, g) Image from sample I-2 (scales in $\mathrm{cm}$ ). development of mosaics was attained in the third century $\mathrm{BC}$ when the regular use of tesserae made with different materials definitively increased the variety of colours and shapes.

In the Iberian Peninsula the most ancient mosaics are dated between the seventh and the fourth centuries BC. They were produced with small stones which formed simple geometrical motifs. After the Roman conquest (third to second century BC), mosaic craftsmen coming from the Lazio were settled in the main cities of the Iberian Peninsula. They founded local workshops in which they made mosaics following Italic techniques and motifs. Polychrome tesserae started to be used in the second century AD, contemporary to the white and black pavement that was still used up to the fourth century AD (2-4).

The ancient city of Italica (Santiponce, Seville) is an example of the wide variety of mosaics. In this site more than one hundred mosaic pavements have been documented. Among them there are big rich polychrome decorated mosaics, as well as other simpler and less luxury. Unfortunately, a great part of these mosaics has been lost as a consequence of spoliation or poor conservation. In addition, those conserved are subjected to weathering conditions such as sun, rain and frost, as well as to local fauna and flora which attacked and disintegrated them slowly (5). In previous works carried out on several mosaics from Italica, the advanced biodeterioration experienced by both tesserae $(6,7)$ and mortars $(8,9)$ has been shown.

The main objective of the present research was the characterization of two sets of building materials formed by glass tesserae and mortar fragments from a mosaic of Carmona and three mosaics of Italica. The characterization was undertaken with the purpose to determine their chemical composition and to evaluate their state of conservation in order to diagnose deterioration mechanisms developed on such materials. Finally, this work was also focussed on determining some technological aspects concerning production of these materials.

\section{EXPERIMENTAL PART}

\subsection{Description of samples}

Two sample sets from Carmona and Italica (Seville) have been studied. Samples from Carmona belonged to a mosaic fragment recently discovered during public works. The fragment corresponds to the right bottom part of a big mosaic that represent the four seasons. The first set is composed of one complete tessera, seven tessera fragments and four mortar fragments (Table 1). The tessera fragments were directly taken from the inner side of the mosaic (Figures $1 \mathrm{~b}$ and $1 \mathrm{c}$ ). 
The mortar fragments showed remains of silica gel layers from the tesserae to which they were adhered (Figures 1e and 1f). The colour indicated in Table 1 for mortar samples refers to the colour of this silica gel layer.

The second set of samples belonged to three different mosaics dated on the second century AD from the city of Italica (Santiponce, Seville): the Neptune mosaic from the Neptune House, the Planetary mosaic from the Planetary House and the Tellus mosaic from the Birds House. The set is composed of 5 samples: one complete tessera, three tessera fragments and one grip mortar to which a glassy tessera and a calcareous tessera were adhered (Table 1 ). None of the samples is higher than $2 \mathrm{~cm}$ in length (Figures $1 \mathrm{~d}$ and $1 \mathrm{~g}$ ). The Tellus samples presented, when they were taken before 1991, some parts of the original mortar and evidences of the biodeterioration caused by lichens (7).

\subsection{Characterization techniques}

The characterization techniques used to study the set of samples have been the following: binocular microscope, scanning electron microscopy and energy dispersive X-ray spectrometry (SEM-EDS), reflection visible spectrophotometry, X-ray diffraction (XRD) and petrographic analysis.

Binocular microscope observations were undertaken with a Leica model MZ16, provided with a digital camera Leica model DC300. SEM observations were carried out with a Hitachi microscope model S-3400-N (CCHS). The samples were observed on their surface and on a polished cross-section. Prior to observations the samples were coated with carbon as a conductive medium, by using a Sputter Coater Polaron SC7620. EDS microanalysis were accomplished with a spectrometer Bruker AXS (133 eV) attached to the electronic microscope.

The study of chromophores was undertaken by reflection visible spectrophotometry with an equipment Ocean Optics model HR 4000 CG. Spectra were recorded in the 250-1100 nm wavelength range.

Crystalline phases were determined with a Phillips X'Pert MPD diffractometer, using the copper $\mathrm{K} \alpha$ radiation $(1.54056 \AA)$, under working conditions of $45 \mathrm{kV}$ and 40 $\mathrm{mA}$. X-ray diffractograms were recorded between $2 \theta=$ $5-60^{\circ}$ on powdered samples obtained in an agate mortar to a grain size lower than $30 \mu \mathrm{m}$.

Petrographic analysis was carried out with a light transmitted optical microscope Kyowa model Bio-Pol 2, equipped with a polarization device and a rotating platen. Petrographic micrographs were obtained with a digital camera Leica model DFC 480.

\section{RESULTS AND DISCUSSION}

\subsection{Surface characterization of glasses}

\section{Samples from Carmona}

Samples from the mosaic of Carmona showed breaks, cracks and wearing. Moreover, all the tesserae presented

Table 1

Description of the samples studied.

\begin{tabular}{|c|c|c|c|}
\hline Name $^{\text {a }}$ & Mosaic & Sample & Colour \\
\hline C -1 & Four season & Tessera fragment & Turquoise \\
\hline C-2 & Four season & Complete tessera & Green \\
\hline C-3 & Four season & Mortar & Green \\
\hline C-4 -5 & Four season & Mortar & White \\
\hline C-6 & Four season & Mortar & Greyish blue \\
\hline C-7 & Four season & Tessera fragment & Dark blue \\
\hline C-8 & Four season & Tessera fragment & Dark blue \\
\hline C-9 -10 & Four season & Tessera fragment & Grey \\
\hline C-11 & Four season & Tessera fragment & Grey \\
\hline C-12 & Four season & Tessera fragment & Turquoise \\
\hline I-1 & Four season & Tessera fragment & Dark green \\
\hline I-2 & Four season & Tessera fragment & Dark blue \\
\hline I-3 & Neptune & Mortar with tesserae & Greyish blue \\
\hline I-4 & Neptune & Tessera fragment & Dark green \\
\hline I-5 & Planetary & Tessera fragment & Complete tessera \\
\hline
\end{tabular}

a Abbreviations: C (Carmona), I (Italica). 
iridescent silica gel layers (Figure 2a). Such iridescent layers are due to surface dealkalinization. The soil humidity directly in contact with the mosaic pieces causes the ion-exchange of water protons $\mathrm{H}^{+}$with the alkaline ions from the alkaline and earth-alkaline oxides of the glass $\left(\mathrm{Na}_{2} \mathrm{O}, \mathrm{K}_{2} \mathrm{O}, \mathrm{MgO}\right)$ following the reaction [1].

$\mathrm{H}_{2} \mathrm{O} \rightarrow \mathrm{H}^{+}+\mathrm{OH}^{-}$

$\equiv \mathrm{Si}-\mathrm{O}^{-} \mathrm{R}^{+}+\mathrm{H}^{+}+\mathrm{OH}^{-} \leftrightarrow \equiv \mathrm{Si}-\mathrm{OH}^{-}+\mathrm{R}^{+}+\mathrm{OH}^{-}$

$\left(\mathrm{R}^{+}=\right.$alkaline ion)

Humidity is propagated through the cracks and breaks of the mosaic pieces. That is why iridescent layers are also formed in the inner part of the tesserae, which could affect the mechanical integrity of the piece (Figures $2 \mathrm{a}$ and $2 \mathrm{~d}$ ). Silica gel layers showed white or yellowish colouring.

In between iridescent layers of the glass samples, dark dendritic deposits were detected (Figures $2 b$ and $2 e$ ). Sometimes such deposits coated the entire sample surface, as can be observed in sample C-10. EDS microanalyses carried out on the dark deposits of the most attacked samples (samples C-2, C-10 and C-11) showed a high content of lead oxide $(\mathrm{PbO})$, iron oxide $\left(\mathrm{Fe}_{2} \mathrm{O}_{3}\right)$ and manganese oxide ( $\mathrm{MnO}$ ) (Table 2).
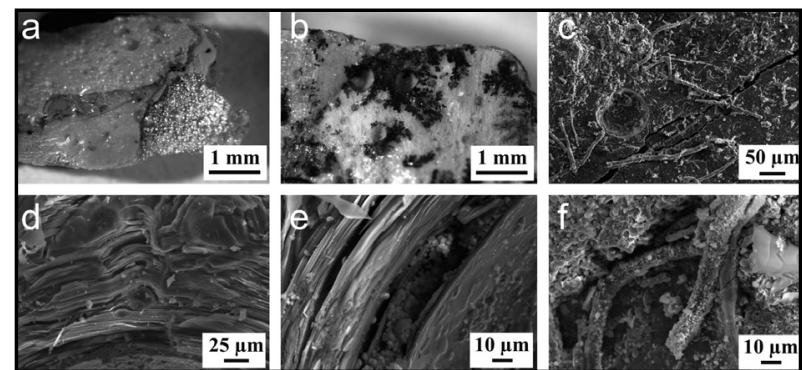

Figure 2. a) Binocular microscope image of the iridescent layer from sample $\mathrm{C}-1$, b) Binocular microscope image of dark deposits from sample C-11, c) SEM micrograph of calcareous deposits from sample C-10, d) SEM micrograph of iridescent layers from sample C-10, e) SEM micrograph of dark deposits from sample C-10, f) SEM micrograph of calcareous deposits from sample $\mathrm{C}-12$.

On the surface of samples C-10, C-11 and C-12 some filamentous structures were observed containing a high calcium percentage (Figures $2 \mathrm{c}$ and $2 \mathrm{f}$ ), which could be the result of biological activity in the past.

\section{Samples from Italica}

The tessera fragments from Italica showed the usual pathologies of a chemical attack developed after biological interaction (Figure 3a), as previous works conducted with similar pieces demonstrated (7), even though some tessera surfaces did not show evidences of the biological attack (Figure 3b).

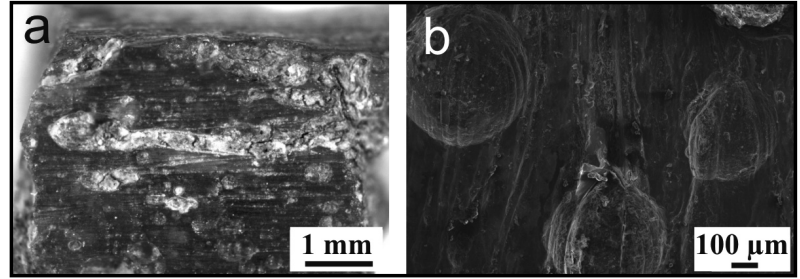

Figure 3. a) Binocular microscope image of evidences of biological attack in sample I-1, b) SEM micrograph from the surface of sample I-1.

\subsection{Characterization of the glass bulk}

The glass bulk characterization of tesserae gathers valuable information on the original glass since, in contrast to the surface, it has not experienced deterioration processes. From a total of 17 samples, only 4 (C-2, C-10, C-11 and I-2) presented a sufficient size to undertake a confident study of the glass bulk of the piece.

\section{Samples from Carmona}

The chemical composition of samples C-2, C-10 and C-11 corresponds to a soda lime silicate glass (Table 2). This is the common composition of most Roman glasses of this chronology. The macroscopic observation from the bulk of pieces revealed a glass with many bubbles and not melted inclusions with brown and black colours (Figure 4). This indicated a low quality and poor refined glass.

The sample C-2 is an opal glass, turquoise blue coloured. EDS microanalyses carried out on its polished surface, and consequently on the bulk glass, showed a high content of antimony oxide $\left(\mathrm{Sb}_{2} \mathrm{O}_{3}=3.9 \mathrm{wt}\right.$. \%) (Table 2) that could be attributed to the presence of calcium antimonite. This compound was used in the Iberian Peninsula up to the fifth century $A D$ as an opacifying agent (1012). On the contrary, samples $\mathrm{C}-10$ and $\mathrm{C}-11$ are translucent glasses with a $\mathrm{Sb}_{2} \mathrm{O}_{3}$ content lower than 2.5 wt. \% (Table 2).

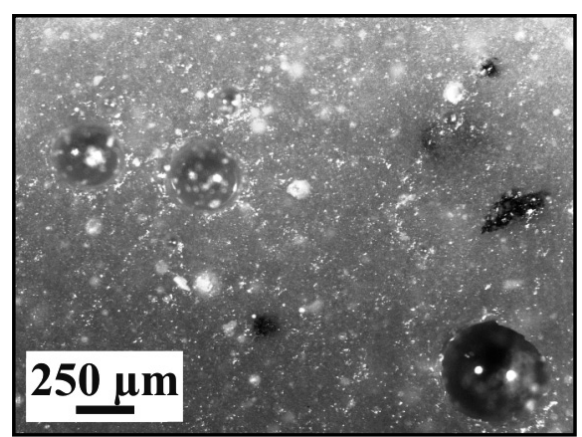

Figure 4. Binocular microscope image of bubbles and not melted particles from sample C-2. 
Table 2

Average results of EDS microanalyses of the samples studied.

\begin{tabular}{|c|c|c|c|c|c|c|c|c|c|c|c|c|}
\hline \multirow{3}{*}{$\begin{array}{l}\text { Comp. } \\
\text { (wt. \%) }\end{array}$} & \multicolumn{12}{|c|}{ Samples a } \\
\hline & \multicolumn{2}{|c|}{$C-2$} & \multicolumn{4}{|c|}{ C-4 } & \multicolumn{2}{|c|}{ C-10 } & \multicolumn{2}{|c|}{ C-11 } & \multicolumn{2}{|c|}{ I-2 } \\
\hline & Int. & Dep. & Iris. & Dep. & C. roja & Mort. & Int. & Dep. & Int. & Dep. & Int. & Mort. \\
\hline $\mathrm{Na}_{2} \mathrm{O}$ & 16.9 & 0.3 & 1.4 & 0.9 & 0.1 & 0.4 & 20.6 & 0.4 & 17.0 & 0.7 & 6.8 & 0.4 \\
\hline $\mathrm{MgO}$ & 0.7 & 1.2 & 0.9 & 2.0 & 0.2 & 0.2 & 0.7 & 0.8 & 0.3 & 1.2 & 0.6 & 2.3 \\
\hline $\mathrm{Al}_{2} \mathrm{O}_{3}$ & 2.5 & 9.6 & 10.6 & 10.7 & 2.1 & 1.6 & 3.0 & 5.7 & 2.2 & 5.8 & 3.0 & 8.3 \\
\hline $\mathrm{SiO}_{2}$ & 56.1 & 31.2 & 61.7 & 20.3 & 8.5 & 6.9 & 61.9 & 28.0 & 66.7 & 32.5 & 41.5 & 21.0 \\
\hline $\mathrm{P}_{2} \mathrm{O}_{5}$ & 0.2 & 1.8 & 0.2 & 1.0 & 0.1 & 0.4 & 0.1 & 1.6 & n.d. & 1.2 & 0.1 & 2.8 \\
\hline $\mathrm{SO}_{2}$ & 0.1 & n.d. & n.d. & n.d. & n.d. & n.d. & n.d. & n.d. & n.d. & n.d. & n.d. & n.d. \\
\hline $\mathrm{Cl}^{-}$ & 0.7 & 0.4 & n.d. & n.d. & n.d. & 0.2 & 1.1 & 0.4 & 1.0 & 0.3 & 0.8 & 0.2 \\
\hline $\mathrm{K}_{2} \mathrm{O}$ & 1.2 & 2.6 & 4.8 & 2.3 & 1.0 & 0.7 & 0.7 & 2.4 & 0.8 & 1.7 & 0.5 & 1.5 \\
\hline $\mathrm{CaO}$ & 8.5 & 25.8 & 9.9 & 42.9 & 66.4 & 87.8 & 7.4 & 14.8 & 7.2 & 16.0 & 7.5 & 56.9 \\
\hline $\mathrm{TiO}_{2}$ & 0.4 & 1.3 & 0.8 & 1.4 & 0.6 & n.d. & 0.4 & 3.6 & 0.2 & 3.6 & n.d. & 0.7 \\
\hline $\mathrm{MnO}$ & 0.8 & 7.8 & 0.2 & 5.0 & 0.6 & n.d. & 0.9 & 19.5 & 0.5 & 13.6 & 0.2 & n.d. \\
\hline $\mathrm{Fe}_{2} \mathrm{O}_{3}$ & 1.1 & 10.5 & 3.2 & 10.2 & 19.2 & 1.6 & 1.0 & 16.4 & 1.0 & 12.9 & 4.9 & 3.7 \\
\hline $\mathrm{CoO}$ & n.d. & n.d. & n.d. & n.d. & n.d. & n.d. & n.d. & 1.4 & n.d. & 1.2 & n.d. & n.d. \\
\hline $\mathrm{CuO}$ & 5.9 & 2.0 & 0.9 & 1.5 & n.d. & n.d. & n.d. & n.d. & n.d. & n.d. & 9.8 & n.d. \\
\hline $\mathrm{Sn}_{2} \mathrm{O}$ & n.d. & n.d. & n.d. & n.d. & n.d. & n.d. & n.d. & n.d. & n.d. & n.d. & 1.9 & n.d. \\
\hline $\mathrm{Sb}_{2} \mathrm{O}_{3}$ & 3.9 & n.d. & 5.0 & n.d. & n.d. & n.d. & 1.5 & n.d. & 2.2 & 0.9 & n.d. & n.d. \\
\hline $\mathrm{PbO}$ & 1.0 & 5.5 & 0.3 & 1.9 & 1.1 & 0.3 & 0.6 & 5.0 & 0.8 & 8.4 & 22.3 & 2.2 \\
\hline
\end{tabular}

a Abbreviations: Int. (sample bulk), Dep. (dark deposits), Iris. (iridescent layer), C. roja (red layer), Mort. (mortar), n.d. (not detected).

\section{Samples from Italica}

Sample I-2 presented a very different chemical composition in comparison with the other pieces analyzed, either from Italica or Carmona. It is a soda lime silicate glass containing high percentages of lead oxide $(\mathrm{PbO}=22.3 \mathrm{wt} . \%)$ and copper oxide $(\mathrm{CuO}=9.8 \mathrm{wt} . \%)$ (Table 2). This composition is similar to that used in frits and tile enamels of later chronology (fourteenth century $A D$ ) (13), and suggests a possible reusing of wastes from other glasses. However, the restoration and consolidation processes undertaken in this mosaic during the twentieth century, in which some polyester tesserae and glass from contemporary bottles were even used, could explain the different composition of this tessera.

\subsection{Characterisation of the glass colours}

The samples studied did not present a sufficient size to prepare a slab (1 $\mathrm{mm}$ in thickness) to be analyzed by absorption spectrophotometry in the visible range. For this reason the study of chromophores was undertaken by visible reflection spectrophotometry, even though the signal obtained by this method is weaker and less resolved than that obtained by the absorption method. In most cases the habit of the spectra did not allow the complete assignment of chromophores.

\section{Samples from Carmona}

The study of samples C-2, C-10 and C-11 was carried out on a clean and polished surface of the pieces. The reflection spectrum of sample C-2 showed the characteristic band of $\mathrm{Fe}^{2+-i o n s}(1007 \mathrm{~nm})$. The turquoise colouring and the EDS analysis of this piece (Table 2) indicate the overlapping of the $\mathrm{Fe}^{2+-}$-ion band with that of the $\mathrm{Cu}^{2+-i o n}$ (not resolved in the spectrum). The spectrum of the dark blue sample $\mathrm{C}-10$ presented the characteristic bands of Co2+-ions (535, 591 and $648 \mathrm{~nm}$, respectively) and $\mathrm{Fe}^{2+}$-ions $(1011 \mathrm{~nm})$. In the spectrum of sample C-11, the reflection bands of $\mathrm{Fe}^{3+-}$-ions $(377,420$ and $460 \mathrm{~nm}$, respectively) were assigned (Figure 5 ).

\section{Samples from Italica}

Chromophores characterization was carried out on the surface of the glass samples I-1, I-3, I-4 and I-5, even though the surface irregularity diminished notably the spectra resolution. The habit of the spectra from samples I-1 and I-5 did not allow a conclusive assignment of chromophores. The spectrum of sample I-3 (dark blue) showed the absorption bands of $\mathrm{Co}^{2+}$-ions at 536, 592 and $649 \mathrm{~nm}$, respectively. In the reflection spectrum of sample I-4, the bands of such ions were assigned at 540, 596 and $651 \mathrm{~nm}$, respectively, as well as the bands of $\mathrm{Fe}^{3+-}$-ions at 380, 425 and $457 \mathrm{~nm}$ (Figure 5). The blue greyish colour of the sample is attributed to 
the chromatic combination of both chromophores: cobalt and iron.

\subsection{Characterization of the mortar}

The mortar is the layer, together with the nucleus, the rudus and the statumen, on which the tesserae are placed (Figure 1a). Mortar samples C-3, C-4 and C-6 presented remains of iridescent layers from the corresponding extracted tesserae, whereas sample I-2 exhibited two tesserae adhered, one of them glassy and the other calcareous.

\section{Samples from Carmona}

Crystalline phases detected by XRD (calcite and quartz) (Figure 6a), petrographic results (Figure $6 b$ ) and the mortar chemical composition (87.8 $\mathrm{CaO}, 6.9 \mathrm{SiO}_{2}$ wt. \%) indicated the use of a lime mortar with a small proportion of silica sand. This kind of mortar is commonly used in mosaics of this chronology. Sample C-4 is the only one with an additional red layer between the mortar and the iridescent layer, showing variable thickness and porous appearance (Figure 7a and 7b). Its EDS analysis (Table 2) indicated a high content of $\mathrm{Fe}_{2} \mathrm{O}_{3}$ (19.2 wt. \%). This layer could be related to the sinopia used by craftsmen to elaborate the design prior to the mosaic production $(1,2)$. Between the red layer and the iridescent layer another fine stratum with high contents of iron oxide $\left(\mathrm{Fe}_{2} \mathrm{O}_{3}\right)$, manganese oxide ( $\mathrm{MnO}$ ) and lead oxide (PbO) (Table 2) (Figures 7b, 7c and 7d) was located. Such fine stratum is connected with dark deposits found in other pieces (section 3.1, Samples from Carmona).

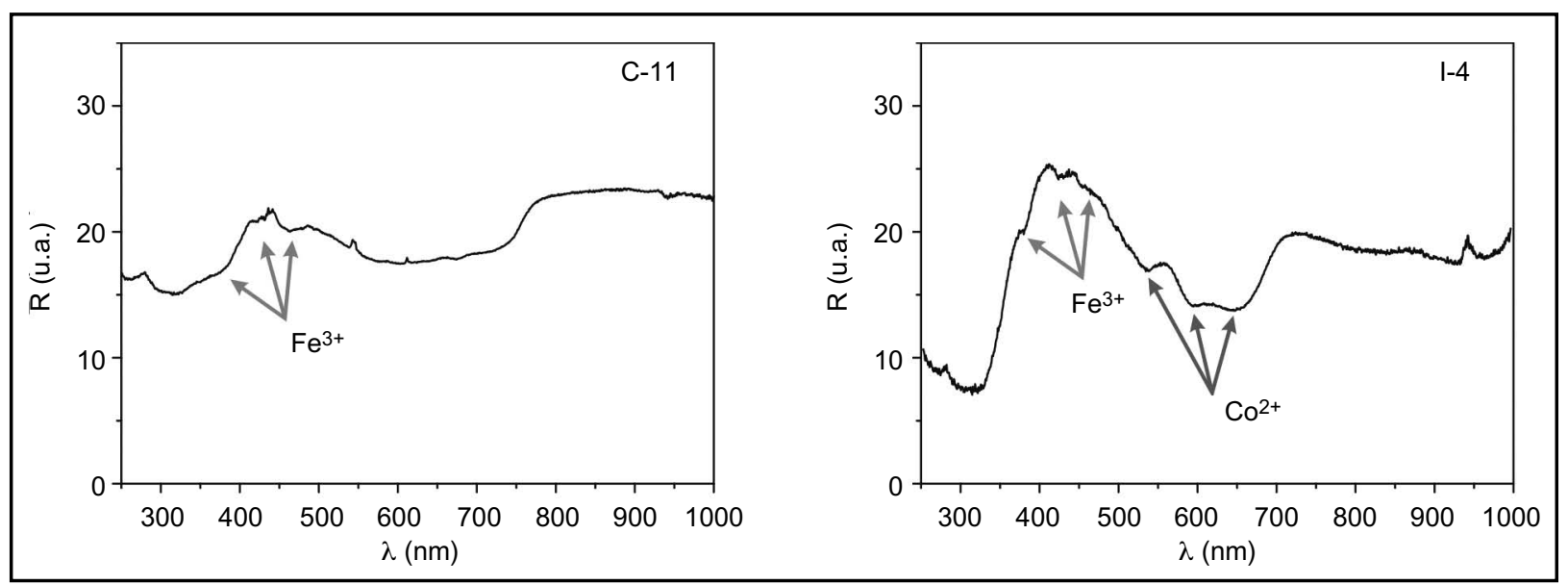

Figure 5. Optical reflection spectra from samples C-11 (grey) and I-4 (greyish blue).

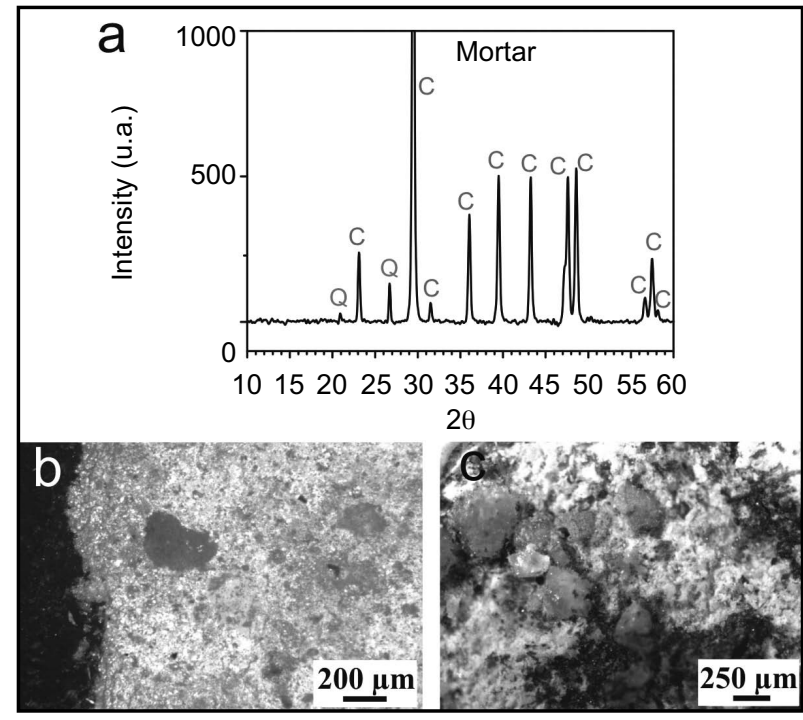

Figure 6. a) X-ray diffractogram of the mortar from Carmona,

b) Thin section image of the mortar from Carmona, c) Binocular microscope image of the mortar from Italica.
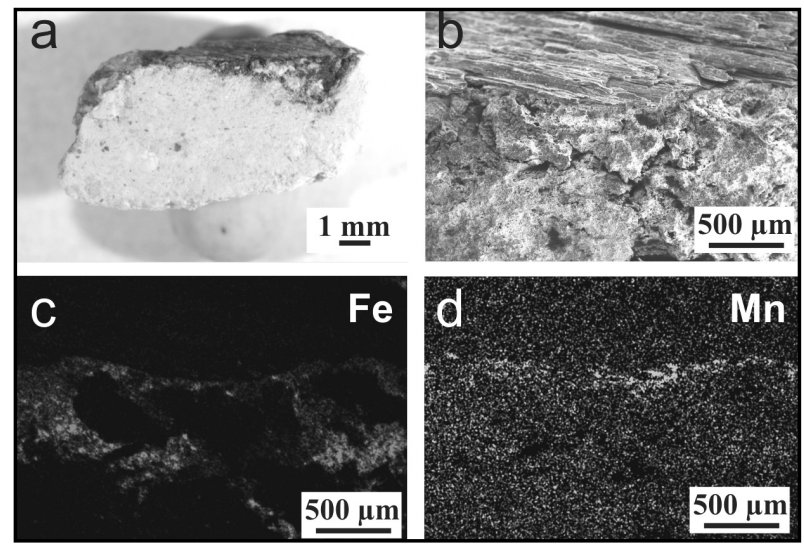

Figure 7. a) Binocular microscope image of the different layers from sample C-4, b) SEM micrograph of the different layers from sample $C-4$, c y d) Mapping of the different layers from sample C-4. 


\section{Samples from Italica}

Sample I-2 is a mortar fragment adhered to a glassy tessera and a calcareous tessera. On its surface big sand grains $(250 \mu \mathrm{m})$ have been detected, as well as lichen remains described in previous works (9) (Figure 6c). EDS surface microanalysis of the mortar showed a lower concentration of $\mathrm{CaO}$ and higher content of $\mathrm{SiO}_{2}$ and $\mathrm{MgO}$ (Table 2). This result could indicate that this lime mortar contains more silica sand than that used in the mosaic from Carmona. The presence of other crystalline phases, as dolomite, albite or aragonite, identified in mortars of the same chronology (14) must not be discarded. This mosaic was consolidated and restored with reposition materials and filling mortars in the twentieth century. Therefore, it is not possible to assign a Roman origin for this mortar.

\section{CONCLUSIONS}

The characterization of a set of mosaic samples from Carmona and Italica determined the chemical composition of the glass tesserae and their state of conservation. The majority of tesserae were produced with soda lime silicate glass, which is the common composition of Roman glasses used for tableware pieces and windows. Nevertheless, one of the samples from Italica showed a different chemical composition characterized by high contents of lead and copper oxides. Such composition could suggest the reusing or recycling of contemporary glass wastes. Moreover, the presence of bubbles, strings and not melted particles in the tesserae indicates the use of a low quality glass in comparison with that used in tableware glass.

Samples from the mosaic of Carmona showed a severe surface deterioration. The deep dealkalinization process experienced by the pieces caused the formation of thick iridescent layers which, together with dark deposits, have completely transformed the surface. In addition, deterioration has also damaged the integrity of the pieces since they were irreversibly fissured, fractured and fragmented. On the contrary, samples from Italica showed evidences of a chemical attack from biological origin. Such samples have been subjected to the attack of lichens, due to their outdoor exposition for many decades in which no cleaning or maintenance treatments were accomplished.

\section{ACKNOWLEDGEMENTS}

The authors acknowledge partial financial support from programs Consolider Ingenio 2010 Ref. TCP-CSD 200700058 and Geomateriales ref. S2009/MAT-1629, as well as professional support from TECHNO-HERITAGE (Network of Science and Technology for Heritage Conservation). T.P. acknowledges a pre-doctoral FPU grant from the Spanish Ministry of Science and Innovation (MICINN).

\section{BIBLIOGRAPHY}

(1) Carrascosa Moliner, T.: La conservación y restauración del mosaico, Universidad Politécnica de Valencia, Valencia (2004).

(2) Dunbabin, K. M. D.: Mosaics of the Greek and Roman World, Cambridge University Press, Nueva York (1999).

(3) Blázquez, J. M. "El mosaico romano en Hispania", http://www.cervantesvirtual.com/FichaObra.html?Ref=21223\&portal=114

(4) Ramallo Asensio, S.: "Talleres y escuelas musivas en la Península Ibérica", en Mosaicos Romanos. Estudios sobre iconografía, Asociación Española del Mosaico, Guadalajara (1990).

(5) García y Bellido, A.: Andalucía monumental. Itálica, Editoriales Andaluzas Unidas, Sevilla (1985).

(6) García-Rowe, J.; Saiz-Jiménez, C.: "Colonization of mosaics by lichens: the case study of Italica (Spain)", Studia Geobotanica, vol. 8 (1988), pp. 65-71.

(7) Saiz-Jiménez, C.; García-Rowe, J.; Rodríguez-Hidalgo, J. M.: "Biodeterioration of polychrome Roman mosaics", International Biodeterioration, vol. 28 (1991), pp. 65-79. http://dx.doi.org/10.1016/0265-3036(91)90034-O

(8) Puertas, F.; Blanco-Varela, M. T.; Palomo, A.; Ortega-Calvo, J. J.; Ariño, X.; Saiz-Jimenez, C.: "Decay of Roman and repair mortars in mosaics from Italica, Spain", The Science of the Total Environment, vol. 153 (1994), pp. 123-131. http://dx.doi.org/10.1016/0048-9697(94)90109-0

(9) Ariño, X., Gómez-Bolea, A., Saiz-Jiménez, C.: "Lichens on ancient mortars", International Biodeterioration \& Biodegradation, vol. 40, no 2-4 (1997), pp. 217-224. http://dx.doi.org/10.1016/S0964-8305(97)00036-X, PMCid:373060 (10) Tite, M.; Pradell, T.; Shortland, A.: "Discovery, production and use of tin-based opacifiers in glasses, enamels and glazes from the Late Iron Age onwards: a reassessment", Archaeometry, vol. 50, no 1 (2008), pp. 67-84.

(11) Ricciardi, P.; Colomban, P.; Tournié, A.; Macchiarola, M.; Ayed, N.: "A non-invasive study of Roman Age mosaic glass tesserae by means of Raman spectroscopy", Journal of Archaeological Science, vol. 36, no 11 (2009), pp. 2551-2559. http://dx.doi.org/10.1016/j.jas.2009.07.008 
(12) Foster, H. E.; Jackson, C. M.: "'A whiter shade of pale'? Chemical and experimental investigation of opaque white Roman glass gaming counters", Glass Technology, vol. 46, no 5 (2005), pp. 327-333.

(13) Rincón, J. M.; Blanco, M. T.; Sánchez-Rojas, M. I.; Romero, M.: "Colours from the glazed tiles inserted in the Blaster Mudejar façade of Pedro I, Sevilla Royal Palaces", en Colours 2008: Bridging Science with Art (2008), Universidade de Évora, Évora.

(14) Fernández Rodríguez, J. M.; Fernández Fernández, J. A.: "Caracterización físico-química de los morteros romanos de El Ruedo (Almedinilla, Córdoba)", Materiales de Construcción, vol. 54, no 275 (2004), pp. 39-51. 